\title{
Analisa Kualitas Layanan Sistem Smart Unilak Menggunakan Servqual Method
}

\author{
Syahtriatna Djusar ${ }^{1}$, Muhamad Sadar $^{2}$, Elvira Asril ${ }^{3}$ \\ ${ }^{1,3}$ Program Studi Sistem Informasi Fakultas Ilmu Komputer Universitas Lancang Kuning \\ ${ }^{2}$ Program Studi Teknik Informatika Fakultas Ilmu Komputer Universitas Lancang Kuning \\ 1,2,3 Jl. Yos Sudarso KM. 8 Rumbai, Pekanbaru, Riau, telp. 08117532015 \\ e-mail: ${ }^{1}$ eet@unilak.ac.id, ${ }^{2}$ sadar@ unilak.ac.id, ${ }^{3}$ elvira@ unilak.ac.id
}

\begin{abstract}
Abstrak
Keberhasilan suatu layanan, dilihat dari sisi pandang / persepsi user dari Sistem Informasi tersebut. Pengguna menggunakan persepsinya, untuk menilai secara keseluruhan terhadap kualitas sistem informasi. Tujuan dari penelitian ini untuk mengetahui pengaruh dimensi Service Quality (servqual) yakni Tangibles, Reliability, Responsiveness, Assurance dan Empathy, terhadap Kualitas Layanan yang terkait dengan Kepuasan Mahasiswa sebagai Pengguna SMART Unilak di layanan PDPT Unilak. Dari 981 mahasiswa Fasilkom, maka yang menjadi objek penelitian ini adalah 64 mahasiswa yang mengisi kuisioner dan sesuai kriteria. Dalam penelitian ini teknik sampling yang digunakan yaitu Nonprobability sampling dengan teknik purposive sampling dengan kriteria yang ditetapkan adalah mahasiswa aktif, pernah menggunakan Smart Unilak dan pernah berhubungan langsung dengan layanan PDPT Unilak. Hasil uji korelasi memperlihatkan hubungan positif serta signifikan dari 5 (lima) variable bebas, yaitu variabel assurance, tangible, reliability, responsiveness, serta empathy dari Kualitas Layanan Sistem Informasi SMART Unilak. Kontribusi variabel tangibles; reliabilitys; responsivenes; assurance, serta empathy untuk menambah Kualitas Layanan pada PDPT Unilak secara berurutan adalah sebesar 17.90\%, 4.60\%, 30.76\%, 45.92\%, -11.13\%. Sesuai perhitungan skor Service Quality, maka diperoleh kesenjangan atau Gap untuk masing-masing variabel bebas yiatu tangibl; reliability; responsiveness; assurance; dan empathy yang nilainya secara berurut adalah -0.8, -0.55, -0.69, -0.75, -0.59. Hasil penelitian menunjukkan masih kurang baiknya kualitas dari tangible; reliability; responsiveness; assurance; dan empathy, serta tingkat kepuasan pengguna terhadap Kualitas Layanan Sistem Informasi SMART Unilak pada PDPT Unilak masih kurang puas.
\end{abstract}

Kata kunci: Kualitas Layanan, Smart Unilak, Servqual, Sistem Informasi

\begin{abstract}
The success of a service, seen from the point of view / user perception of the Information System. Users use their perceptions, to assess the overall quality of the information system. The purpose of this study was to determine the effect of Service Quality (servqual) dimensions, namely Tangibles, Reliability, Responsiveness, Assurance and Empathy, on Service Quality related to Student Satisfaction as Unilak SMART Users in Unilak PDPT services. Of the 981 students of Fasilkom, 64 students filled out the questionnaire according to the criteria. In this study, the sampling technique used was nonprobability sampling with purposive sampling technique with the criteria set were active students, had used Smart Unilak and had direct contact with PDPT Unilak services. The results of the correlation test show a positive and significant relationship from 5 (five) independent variables, namely the assurance, tangible, reliability, responsiveness, and empathy variables of the Unilak SMART Information System Service Quality. Contribution of the tangibles variable; reliabilitys; responsivenes; assurance, and empathy to increase Service Quality at PDPT Unilak were 17.90\%, 4.60\%, 30.76\%, $45.92 \%,-11.13 \%$, respectively. In accordance with the calculation of the Service Quality score, a gap is obtained for each of the independent variables, namely tangibl; reliability;


responsiveness; assurance; and empathy whose values are $-0.8,-0.55,-0.69,-0.75,-0.59$ respectively. The results showed that the quality of the tangible was not good enough; reliability; responsiveness; assurance; and empathy, and the level of user satisfaction with the Unilak SMART Information System Service Quality at PDPT Unilak is still not satisfied.

Keywords: Service of Quality, Smart Unilak, Servqual, Information Systems.

\section{Pendahuluan}

Kepuasan pengguna suatu Sistem Informasi menjadi suatu faktor atau tolak ukur dari keberhasilan suatu aktifitas pemanfaatan dan penggunaan Sistem Informasi dalam instansi / perusahaan, hal ini akan terkait dengan loyalitas dari pengguna[1][2]. Keberhasilan suatu layanan dilihat dari persepsi para pengguna suatu Sistem Informasi [3]. Persepsi parapengguna terkait kualitas dari pelayanan, merupakan penilaian yang lengkap secara keseluruhan terhadap keunggulan dari layanan [4].

Pemberdayaan pemanfaatan teknologi informasi dalam beberapa kegiatan, sudah dilaksanakan oleh Universitas Lancang Kuning untuk meningkatkan kualitas layanan[5], salah satunya adalah aplikasi dalam pengelolaan akademis. Aplikasi ini di beri nama SMART Unilak. SMART Unilak dapat digunakan oleh berbagai tingkat user, sesuai dengan jenis akun yang dimiliki masing-masingnya. Banyaknya modul-modul aplikasi yang tersedia serta beragamnya latar belakang pengguna, membuat aplikasi ini perlu di ukur tingkat kualitas layanannya. Pengukuran ini akan berkait langsung dengan kepuasan pengguna. Salah satu pengguna adalah mahasiswa, namun tidak semua mahasiswa pengguna aplikasi ini yang berhasil menggunakan aplikasi ini sesuai dengan apa yang mereka harapkan. Beberapa mahasiswa pernah mengalami permasalahan dalam penggunaan aplikasi. Apabila mereka tidak dapat menemukan solusi dari permasalahan yang timbul, maka permasalahan yang mereka temukan tersebut, akan disampaikan dan dilaporkan kepada Pangkalan Data Perguruan Tinggi (PDPT) Universitas Lancang Kuning. Layanan yang diberikan PDPT Unilak kepada pengguna juga perlu di ukur dan di evaluasi, karena layanan yang diberikan juga akan terkait dengan kepuasan pengguna sistem informasi tersebut dan akan terkait dengan komitmen dan performa[6]. Hasil dari pengukuran kepuasan pengguna, akan dapat digunakan untuk mengembangkan dan memperbaiki kualitas sistem informasi yang menggunakan aplikasi SMART Unilak.

Penelitian ini bertujuan untuk mengukur kualitas layanan Sistem Informasi SMART Unilak yang diberikan oleh PDPT ke pada mahasiswa Fasilkom Unilak menggunakan skala Servqual. Servqual merupakan scale multiitem yang digunakan untuk menilai persepsi pelanggan tentang kualitas layanan dalam suatu organisasi[7]. Skala tersebut menguraikan pengertian kualitas layanan menjadi lima konstruk sebagai tangible (bukti fisik), reliability (keandalan), responsiveness (daya tanggap), assurance (jaminan), dan empathy (empati). Dengan menggunakan kuisioner, akan dihitung gap antara fakta dan harapan[8][9][10].

Telah ada beberapa penelitian terdahulu yang telah dilakukan terkait dengan pengukuran kualitas sistem informasi pada satu istitusi, diantaranya oleh Mohamad Jebraeily [11], Yohan Wismantoro[12], Wahyudi[13], Utama[14], Paramita[15], Rahayu[16], Ekasari[17][18]. Dari penelitian yang sudah dilakukan sebelumnya, ditemukan celah penelitian yang masuk kedalam jenis Practical-Knowledge Gap, dimana adanya perbedaan kemampuan dari objek penelitian. Pada penelitian yang sebelumnya, objek penelitian bersifat umum. Pada penelitian yang dilaksanakan ini, objek penelitiannya adalah khusus mahasiswa Fasilkom Unilak yang pada dasarnya sudah terbiasa dengan penggunaan aplikasi, sehingga akan memberikan pengaruh kepada hasil pengukuran kuisioner apabila dibandingkan dengan objek yang tidak terbiasa dalam pemanfaatan aplikasi.

\section{Metode Penelitian}

Metode penelitian yang akan diterapkan di penelitian ini menggunakan urutan berpikir metode penelitian sistem informasi. Hevner mengatakan bahwa dalam penelitian bidang sistem 
informasi, terdapat 2 bagian, yakni relevan atau sesuai dengan bidang pengetahuannya (relevance) dan sesuai dengan dasar yang ada (rigor).

\subsection{Desain Penelitian}

Penelitian ini menggunakan desain kausal dan digunakan untuk mengukur pengaruh dari variabel bebas yang dibandingkan dengan variabel terikat. Untuk penelitian ini digunakan variabel bebas yaitu tangible (bukti fisik $)=\mathrm{X} 1$, reliability $($ kehandalan $)=\mathrm{X} 2$, responsivenes $($ daya tanggap $)=\mathrm{X} 3$ dan assurance $($ jaminan $)=\mathrm{X} 4$, serta empathy $($ empati $)=\mathrm{X} 5$. dan variabel terikat adalah Kualitas Layanan Sistem Informasi berdasarkan Kepuasan Dari Pengguna Layanan SMART Unilak(Y). Dalam Penelitian ini akan dilihat hubungan variable X1, X2, X3, $\mathrm{X} 4$ dan X5 kepada variable $\mathrm{Y}$.

\subsection{Lokasi Penelitian}

Penelitian ini dilaksanakan pada Universitas Lancang Kuning Pekanbaru Riau, pada Unit Kerja Pangkalan Data Perguruan Tinggi (PDPT). Sebagai Responden dalam penelitin ini adalah para Mahasiswa Fakultas Ilmu Komputer yang menggunakan layanan SMART Unilak dan perah berinteraksi dengan PDPT Universitas Lancang Kuning.

\subsection{Metode Pengumpulan Data}

Teknik pengumpulan data

2.3.1. Wawancara, peneliti melakuan tanya jawab langsung kepada mahasiswa sebagai responden untuk mendapatkan data tertentu.

2.3.2. Kuisioner, penuliti akan menyearkan daftar pertanyaan secara daring kepada responden yang berjumlah 35 pertanyaan, untuk diisi guna mendapatkan informasi yang diperlukan.

2.3.3. Studi Pustaka, peneliti akan melengkapi referensi dan data-data melalui sumber lain, diantaranya seperti jurnal, buku, laporan ilmiah lainnya.

\subsection{Populasi dan Sampel}

Dari 981 mahasiswa Fasilkom, maka yang menjadi objek penelitian ini adalah 64 mahasiswa yang mengisi kuisioner dan sesuai kriteria. Dalam penelitian ini teknik sampling yang digunakan yaitu Nonprobability sampling dengan teknik purposive sampling dengan kriteria yang ditetapkan adalah mahasiswa aktif, pernah menggunakan Smart Unilak dan pernah berhubungan langsung dengan layanan PDPT Unilak.

\subsection{Operasionalisasi Variabel}

Dalam pengumpulan data melalui kusioner ini, digunakan 35 pertanyaan yang akan digunakan untuk mengukur 5 dimensi yang ada. Dari setiap pertanyaan itu akan menjadi sebuah variabel yang menggunakan skala liker dengan rentang nilai/ interval skala 1 sampai 5 . Skor $5=$ Sangat Setuju, Skor $4=$ Setuju, Skor $3=$ Ragu-ragu, Skor $2=$ Tidak Setuju, dan Skor $1=$ Sangat Tidak Setuju. Tabel 1 verisi pertanyaan dan variable yang ada dipenelitian.

Tabel 1. Operasionalisasi Variabel

\begin{tabular}{|c|c|c|c|c|}
\hline No & Pertanyaan & Dimensi & Var & Skala \\
\hline 1 & Ada petunjuk manual penggunaan Smart Unilak & \multirow{7}{*}{$\begin{array}{l}\text { Tangibles (X1) } \\
\text {-Fasilitas } \\
\text {-Pegawai } \\
\text {-Perlengkapan } \\
\text {-Peralatan }\end{array}$} & $\mathrm{X} 11$ & \multirow[t]{7}{*}{ Interval } \\
\hline 2 & Akses Internet mudah di dapatkan di Kawasan & & X12 & \\
\hline 2 & Akses internet selalu ada di tiap Ruang Kuliah & & X13 & \\
\hline 4 & Bandwith sesuai dengan yang di janjikan. & & X14 & \\
\hline 5 & Gedung/ Ruang PDPT Mudah di Jangkau & & $\mathrm{X} 15$ & \\
\hline 6 & Layanan Internet Kampus aktif 24 Jam & & $\mathrm{X} 16$ & \\
\hline 7 & PDPT Memiliki Ruang Layanan yang Memadai & & $\mathrm{X} 17$ & \\
\hline 8 & $\begin{array}{l}\text { Anda merasa aman dalam menggunakan Akses } \\
\text { Internet Kampus }\end{array}$ & \multirow{3}{*}{$\begin{array}{l}\text { Reliability } \\
\text { (X2) } \\
\text {-Konsisten } \\
\text {-Akurat } \\
\text {-Handal }\end{array}$} & X21 & \multirow[t]{3}{*}{ Interval } \\
\hline 9 & $\begin{array}{l}\text { Anda merasa aman ketika menggunakan Smart } \\
\text { Unilak }\end{array}$ & & $\mathrm{X} 22$ & \\
\hline 10 & $\begin{array}{l}\text { Anda percaya kelengkapan dan keakuratan data } \\
\text { Smart Unilak }\end{array}$ & & X23 & \\
\hline
\end{tabular}




\begin{tabular}{|c|c|c|c|c|}
\hline No & Pertanyaan & Dimensi & Var & Skala \\
\hline 11 & PDPT selalu bekerja sesuai SOP & \multirow{3}{*}{$\begin{array}{l}\text { Reliability } \\
\text { (X2) } \\
\text {-Konsisten } \\
\text {-Akurat } \\
\text {-Handal }\end{array}$} & $\mathrm{X} 24$ & \\
\hline 12 & Smart Unilak bisa diakses darimana saja & & $\mathrm{X} 25$ & \\
\hline 13 & $\begin{array}{l}\text { Smart Unilak tidak memiliki Bug (error) pada saat } \\
\text { digunakan }\end{array}$ & & $\mathrm{X} 26$ & \\
\hline 14 & $\begin{array}{l}\text { Menu forgot password (membantu ketika lupa } \\
\text { password) berfungsi baik. }\end{array}$ & \multirow{7}{*}{$\begin{array}{l}\text { Responsivenes } \\
\text { s (X3) } \\
\text {-Kesigapan } \\
\text {-Kecepatan } \\
\text {-Penanganan } \\
\text { Keluhan }\end{array}$} & X31 & \multirow[t]{7}{*}{ Interval } \\
\hline 15 & Menu-menu pada Smart Unilak berfungsi baik. & & $\mathrm{X} 32$ & \\
\hline 16 & $\begin{array}{l}\text { PDPT selalu dapat dihubungi jika terjadi gangguan } \\
\text { jaringan internet kampus }\end{array}$ & & $\mathrm{X} 33$ & \\
\hline 17 & $\begin{array}{l}\text { Smart Unilak memberikan respon cepat ketika di } \\
\text { Akses }\end{array}$ & & $\mathrm{X} 34$ & \\
\hline 18 & $\begin{array}{l}\text { Staf PDPT memiliki jam kerja sesuai dengan yang } \\
\text { anda harapkan }\end{array}$ & & $\mathrm{X} 35$ & \\
\hline 19 & $\begin{array}{l}\text { Tampilan Smart Unilak mudah di pahami dan } \\
\text { digunakan }\end{array}$ & & $\mathrm{X} 36$ & \\
\hline 20 & $\begin{array}{l}\text { Terdapat pemberitahuan jika layanan Internet akan } \\
\text { Non Aktif (dalam perbaikan) }\end{array}$ & & $\mathrm{X} 37$ & \\
\hline 21 & $\begin{array}{l}\text { Anda merasa aman dalam menerima layanan } \\
\text { PDPT }\end{array}$ & \multirow{7}{*}{$\begin{array}{l}\text { Assurance } \\
\text { (X4) } \\
\text {-Kompetensi } \\
\text {-Kesopanan } \\
\text {-Kredibilitas }\end{array}$} & $\mathrm{X} 41$ & \multirow[t]{7}{*}{ Interval } \\
\hline 22 & Jaringan Internet selalu stabil & & $\mathrm{X} 42$ & \\
\hline 23 & Kecepatan akses internet sesuai kebutuhan anda & & $\mathrm{X} 43$ & \\
\hline 24 & $\begin{array}{l}\text { Secara umum anda percaya terkait keamanan data } \\
\text { anda di PDP }\end{array}$ & & $\mathrm{X} 44$ & \\
\hline 25 & Staf PDPT bisa dipercaya & & $\mathrm{X} 45$ & \\
\hline 26 & Staf PDPT memberikan layanan yang cepat & & $\mathrm{X} 46$ & \\
\hline 27 & $\begin{array}{l}\text { Staf PDPT memiliki pengetahuan menjawab } \\
\text { pertanyaan Anda }\end{array}$ & & $\mathrm{X} 47$ & \\
\hline 28 & PDPT selalu memberikan layanan terbaik & \multirow{6}{*}{$\begin{array}{l}\text { Empathy (X5) } \\
\text {-Akses } \\
\text {-Komunikasi } \\
\text {-Pemahaman } \\
\text { Pemakai }\end{array}$} & $\mathrm{X} 51$ & \multirow[t]{6}{*}{ Interval } \\
\hline 29 & Staf PDPT memberi perhatian kepada Anda & & $\mathrm{X} 52$ & \\
\hline 30 & Staf PDPT selalu berkeinginan membantu anda & & $\mathrm{X} 53$ & \\
\hline 31 & Staf PDPT selalu berprilaku ramah kepada Anda & & X54 & \\
\hline 32 & Staf PDPT selalu menanggapi permintaan anda & & X55 & \\
\hline 33 & Staf yang melayani berpenampilan menarik & & $\mathrm{X} 56$ & \\
\hline 34 & Secara umum anda puas dengan layanan di PDP & \multirow{3}{*}{$\begin{array}{l}\text { Kualitas } \\
\text { Layanan (Y) } \\
\text {-Kenyamanan } \\
\text {-Interaksi } \\
\text { Sosial } \\
\text {-Sarana } \\
\end{array}$} & $\mathrm{Y} 1$ & \multirow[t]{3}{*}{ Interval } \\
\hline 35 & $\begin{array}{l}\text { Secara umum anda puas menerima layanan akses } \\
\text { internet kampus }\end{array}$ & & $\mathrm{Y} 2$ & \\
\hline 36 & $\begin{array}{l}\text { Secara umum anda puas menggunakan Smart } \\
\text { Unilak }\end{array}$ & & Y3 & \\
\hline
\end{tabular}

\subsection{Instrumen Penelitian}

Instrumen dari penelitian menggunakan Kuisioner, dan disebarkan secara daring. Data yang diperlukan adalah pendapat responden terhadap kualitas layanan sistem informasi terkait dengan SMART Unilak pada PDPT. Data yang ada akan diklasifikasikan ke sebuah indikator dan data tersebut selanjutnya dikonstruksikan menjadi instrumen kuisioner. Selanjutnya Data yang sudah ada, akan dipakai dalam uji reliabilitas dan validitas. Kemudian dilakukan 
pengukuran cronbach alpha untuk menentukan besarnya nilai dari alat ukur dalam melakukan pengukuran suatu objek. Jika koefisien cronbach alpha memiliki nilai lebih besar dari 0.6, kuisioner disebut reliable. Apabila nilai korelasi F hitung lebih besar dari $r$ standar, maka akan dikatakan kuisioner tersebut valid. Kuisioner dalam penelitian ini menggunakan skala liker dengan rentang nilai/ interval skala 1 sampai 5. Skor 5 = Sangat Setuju, Skor $4=$ Setuju, Skor 3 = Ragu-ragu, Skor 2 = Tidak Setuju, dan Skor 1 = Sangat Tidak Setuju. Jawaban yang ada, selanjutnya dilakukan analisa kiantitatif. Kualitas Layanan yang diukur meliputi responsiveness, assurance, tangibles, reliability serta empathy.

\subsection{Teknik Analisis}

\subsubsection{Deskriptif Kuantitatif}

Statistik deskriptif adalah suatu statistik dasar dalam analisa data dengan mendeskripsikan data yang terkumpul sesuai dengan apa adanya dan tidak membuat sebuah kesimpulan yang berlaku untuk umum atau generalisasi. Ditampilkan dengan grafik atau tabel, diagram lingkaran, perhitungan modus, pictogram, perhitungan median danperhitungan mean. Aktivitas analisis data antara lain mengeumpulkan data sesuai jenis variabel dan jenis responden, membuat tabulasi data sesuai dengan variable dari seluruh responden, menyajikan data setiap variable penelitian, menjawab rumusan masalah dengan melakukan perhitungan, serta menguji hipotesa penelitian.

\subsubsection{Pengujian Validitas serta Pengujian Reliabilitas}

Pengujian validitas dilaksanakan guna menguji sebuah alat ukur dalam bentuk kuisioner dalam mengukur setiap butir kuisioner, yang terkait dengan keaabsahannya. Penggunaan kuisioner dalam penelitian ini, merupakan salah satu cara dalam pengumpulan data, dan untuk mengetahui indeks validitas angket tersebut digunakan rumus product moment correlation dari pearson yakni:

$$
\mathrm{r}=\frac{\mathrm{N} \sum \mathrm{XY}-\sum \mathrm{X} * \sum \mathrm{Y}}{\sqrt{\left[N \sum X 2-\left(\sum X\right) 2\right] *\left[N \sum Y 2-\left(\sum Y\right) 2\right]}}
$$

Korelasi Pearson Product Moment (r) yang disampiakan oleh Karl Pearson tahun 1900. Korelasi ini berguna dalam mengukur derajat hubungan serta kontribusi variable bebas (independen) terhadap variable terikat (dependent).

$\mathrm{r}=$ Korelasi product moment

$\mathrm{Y}=$ Jumlah skor butir variabel $\mathrm{Y}$ pada instrumen

$\mathrm{N}=$ Jumlah Responden

$\mathrm{X}=$ Jumlah skor butir variabel $\mathrm{X}$ pada instrument

Uji reliabilitas digunakan dalam menguji sejauh mana hasil dari pengukuran yang dilakukan, akan bernilai sama jika dilakukan pengukuran ulang. Untuk uji reliabilitas memakai hasil cronbach alpha, hasilnya akan dikatakan reliabel apabila nilainya melebihi 0,6.

\subsubsection{Uji Regresi Linier Berganda}

Pelaksanaan uji ini diperlukan guna mengetahui cara variable dependen dapat diprediksi melalui variable prediktor yang juga dikenal dengan variabel independen secara individual. Hasilnya dipakai dalam memutuskan hubungan antar variabel, apakah bertambah atau berkurangnya nilai variabel dependen dilakukan dengan cara menaikkan dan menurunkan keadaan variabel independen atau menaikkan nilai variabel dependen dengan cara menaikkan nilai variabel independen atau sebaliknya. Analisis regresi berganda digunakan bila jumlah variabel independennya minimal 2, Persamaan regresi untuk dua prediktor adalah :

$$
\mathrm{Y}=\mathrm{a}+\mathrm{b}_{1} \mathrm{X}_{1}+\mathrm{b}_{2} \mathrm{X}_{2}
$$

\subsubsection{Analisa Korelasi}

Analisa korelasi digunnakan untuk mengetahui besaran dalam mengukur kekuatN hubungan antara sebuah variabel dengan variabel lainnya [4]. Besaran korelasi $=\mathrm{r}$ dan simbol untuk parameternya adalah p. Rumus yang digunakan dalam menghitung nilai korelasi:

$$
R_{Y .12}=\sqrt{\frac{b_{1} \sum X_{1} Y+b_{2} \sum X_{2} Y+\ldots \ldots \ldots+b_{n} \sum X_{n} Y}{\sum Y^{2}}}
$$




\section{Hasil dan Pembahasan}

Hasil pengukuran yang dilakukan, adalah untuk mengetahui Kualitas Layanan Sistem Informasi terkait SMART Unilak pada PDPT Universitas Lancang Kuning dengan menggunakan Metode Service Quality (ServQual) untuk mengetahui pengaruh assurance, empathy, tangibles, reliability serta responsiveness terhadap variabel kepuasan mahasiswa pengguna Layanan SMART Unilak dan Sistem Informasi di PDPT.

Variabel bebas yang ada yaitu tengibles $(\mathrm{X} 1)$, meliputi 7 item pertanyaan, reliability (X2), meliputi 6 item pertanyaan, responsiveness (X3 meliputi 7 item pertanyaan, assurance (X4), meliputi 7 item pertanyaan, empathy (X5) meliputi 6 item. Variabel terikat yang diukur yaitu Kepuasan Pengguna Layanan SMART Unilak (Y), yang meliputi 3 buah pertanyaan.

\subsection{Profil Responden}

\subsubsection{Jenis Kelamin}

Adapun jenis kelamin responden terdiri dari dua yaitu pria dan wanita. Kuesioner disebarkan kepada mahasiswa yang memenuhi kriteria dengan jumlah sebanyak 64 orang, maka dilakukanlah identifikasi terhadap responden, hasilnya jumlah reponden pria sebanyak $33(52 \%)$ dan responden wanita sebanyak $3138 \%$ ) orang.

\subsection{Uji Validitas}

Pengujian validitas terkait dengan instrumen suatu penelitian harus dilaksanakan sebelum melakukan tahap uji lainnya. Untuk memudahkan dalam melakukan perhitungan pada Uji validitas, maka di manfaatkan aplikasi SPSS 22. Pengujian validitas dengan memakai bivariate correlations dan correlation coefficiens pearson. Setelah dilaksanakan uji validitas, dengan hasil seperti Tabel 2 dimana seluruh itemnya bernilai berlaku, disebabkan $r$ hitung $>r$ ditabel, dimana $r$ pada tabel $=0.244$. Dari hasil ini memberikan makna bahwa semua variabel digunakan untuk analisis korelasi. Uji reliabilitas dilakukan dengan mencari nilai Cronbachs Alpha.

Tabel 2. Nilai Pengujian Validitas

\begin{tabular}{ccc}
\hline & Hasil Pengujian Validitas \\
\hline Variable & PearsonCorrelation & Hasil Uji \\
\hline X11 & 0.701 & Berlaku \\
X12 & 0.692 & Berlaku \\
X13 & 0.707 & Berlaku \\
X14 & 0.803 & Berlaku \\
X15 & 0.733 & Berlaku \\
X16 & 0.687 & Berlaku \\
X17 & 0.693 & Berlaku \\
X21 & 0.654 & Berlaku \\
X22 & 0.755 & Berlaku \\
X23 & 0.816 & Berlaku \\
X24 & 0.829 & Berlaku \\
X25 & 0.383 & Berlaku \\
X26 & 0.644 & Berlaku \\
X31 & 0.714 & Berlaku \\
X32 & 0.800 & Berlaku \\
X33 & 0.650 & Berlaku \\
X34 & 0.844 & Berlaku \\
X35 & 0.784 & Berlaku \\
X36 & 0.692 & Berlaku \\
\hline
\end{tabular}




\begin{tabular}{lcr}
\hline & Hasil Pengujian Validitas \\
\hline Variable & PearsonCorrelation & Hasil Uji \\
\hline X37 & 0.651 & Berlaku \\
X41 & 0.749 & Berlaku \\
X42 & 0.683 & Berlaku \\
X43 & 0.679 & Berlaku \\
X44 & 0.777 & Berlaku \\
X45 & 0.850 & Berlaku \\
X46 & 0.806 & Berlaku \\
X47 & 0.774 & Berlaku \\
X51 & 0.711 & Berlaku \\
X52 & 0.706 & Berlaku \\
X53 & 0.826 & Berlaku \\
X54 & 0.845 & Berlaku \\
X55 & 0.768 & Berlaku \\
X56 & 0.663 & Berlaku \\
Y1 & 0.834 & Berlaku \\
Y2 & 0.702 & Berlaku \\
Y3 & 0.750 & Berlaku \\
Total & 1.000 & Berlaku \\
\hline
\end{tabular}

\subsection{Uji Reliabilitas}

Untuk menyimpulkan hasil dari uji reliabilitas, dengan memperhatikan nilai Cronbach's Alpha, apabila nilai Cronbach's Alpha $>0,60$ maka angket atau kuisioner yang digunakan dapat dinyatakan reliabel atau konsisten. Sebaliknya, jika nilai Cronbach's Alpha < 0,60 maka angket atau kuisioner yang digunakan dapat dinyatakan tidak reliabel atau tidak konsisten.

Berdasarkan output Reliability Statistics menggunakan SPSS 22 didapat nilai Cronbach's Alpha $=0.757$, Cronbach's Alpha $>\mathrm{r}$ table, dimana nilai $r$ table $=0.244$. Hasil itu memperlihatkan kuisioner yang disebarkan adalah reliabel atau terpercaya.

\subsection{Uji Regresi Linier Berganda}

Tabel 3. Reliability Statistic

Cronbachs

Dalam mengetahui cara memprediksi variabel dependen melalui prediktor atau variabel independen secara individual maka dilakukan Analisis regresi. Hasilnya digunakan dalam menentukan hubungan naik dan menurunnya variabel dependen dan independen, dimana untuk meningkatkan nilai variabel dependen dilakukan melalui penambahan nilai variabel independen atau sebaliknya dengan menurunkan variabel independen akan menurunkan variabel dependen. Analisis regresi berganda digunakan bilamana variabel independennya minimal 2.

3.4.1. Uji Normalitas

Dalam model regresi, untuk mencari nilai variabel bebas yaitu X1, X2, X3, X4 dan X5 serta variabel terikat yaitu $\mathrm{Y}$, apakah keduanya memiliki distribusi normal, dan atau sebaliknya. Salah satu cara untuk mengetahuinya adalah melihat grapic normal P-P Plot, dengan memperhatikan titik-titiknya, akan tersebar di garis diagonal secara searah. 


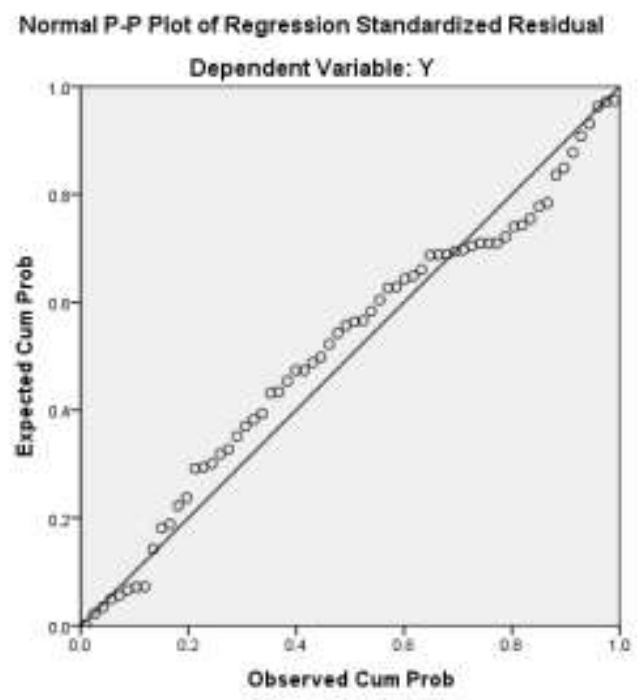

Gambar 1. Normal P-P Plot

Pada diagram Histogram membentuk lengkung kurve normal maka residual dinyatakan normal dan asumsi normalitas terpenuhi.

Menggunakan Shapiro Wilk Nilai sig nilainya sebesar 0,750 lebih dari 0,05, maka dimasukkan kekelompok data berdistribusi Normal, dan pada kolom Kolmogorov-Smirnova sig nilainya $0,200>0,05$, maka data akan berdistribusi Normal dan $\mathrm{H} 0$ diterima.

Tabel 4. Tests of Normality

\begin{tabular}{lccccccc}
\hline & \multicolumn{3}{c}{ Kolmogorov-Smirnov $^{\text {a }}$} & \multicolumn{3}{c}{ Shapiro-Wilk } \\
\cline { 2 - 9 } & Statistic & df & Sig. & Statistic & df & Sig. \\
\hline Unstandardized Residual & .085 & 64 & $.200^{*}$ & .966 & 64 & .075 \\
\hline
\end{tabular}

\subsubsection{Uji Heteroskedastisitas}

Uji Heteroskedastisitas adalah uji yang menilai apakah ada ketidaksamaan varian dari residual untuk semua pengamatan pada model regresi linear. Pengujian Heteroskedastisitas digunakan dalam mengukur pertanyaan, terkait apakah di model regresi telah terjadi nilai ketidaksamaan varians dalam sebuah residual pengamatan kepada nilai pengamatan yang lain. Pada penelitian ini yang ditunjukkan oleh grafik scatterplot terlihat titik-titik yang menyebar secara acak dan data menyebar dengan baik diatas dan dibawah angka 0 pada sumbu $\mathrm{Y}$, hal ini dapat diartikan tidak terjadi Heteroskedastisitas pada model regresi. Karena asumsi heteroskedastisitas terpenuhi, maka model regresi dinyatakan valid sebagai alat peramalan

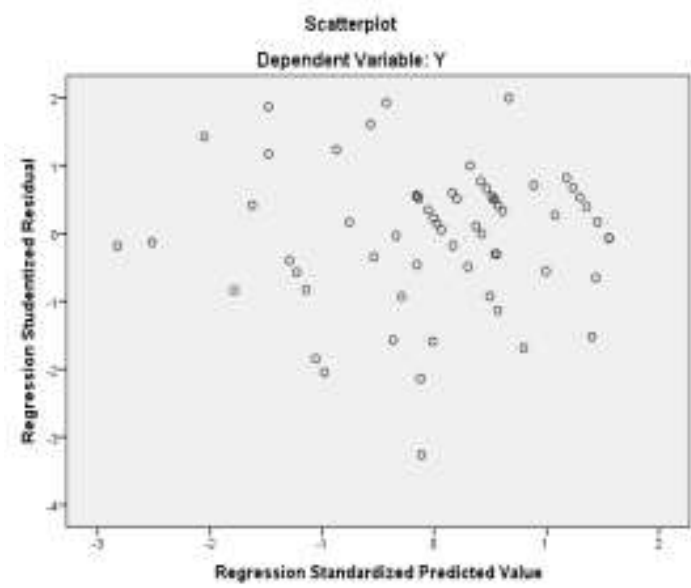

Gambar 2. Grafik Scatterplot 


\subsubsection{Uji Regresi Linier Berganda}

Koefisien determinasi (R kuadrat/ R Square) mempunyai simbol "R2" yang berarti sebagai besarnya pengaruh yang diberikan oleh suatu variabel bebas atau variabel independent (X) kepada variabel terikat atau variabel dependent (Y). Dari hasil terlihat bahwa $\mathrm{R}$ Square = 0.846 , artinya variabel tangible (X1); reliabillitys (X2); responsiveness (X3), asurance (X4) dan empathy (X5) secara bersama akan memberikan pengaruh terhadap variabel Kualitas Layanan (Y) sebesar $84,6 \%$.

Tabel 5. R Square

\begin{tabular}{lrrrr}
\hline Model & R & R Square & $\begin{array}{c}\text { Adjusted R } \\
\text { Square }\end{array}$ & $\begin{array}{l}\text { Std. Error of } \\
\text { the Estimate }\end{array}$ \\
\hline 1 & $.920^{\mathrm{a}}$ & .846 & .832 & .40260 \\
\hline
\end{tabular}

Pengujian Regresi Linear Berganda di kegiatan ini merupakan regresi linear berganda dalam memperkirakan kualitas layanan menggunakan variabel responsiveness, assurance, tangibles, reliability dan empathy, seperti terlihat dalam Tabel 7. Dari tabel yang ada, maka persamaan regresi bergandanya dapat dituliskan : $\mathrm{Y}=0.041+0,177 \mathrm{X} 1+0.059 \mathrm{X} 2+0,364 \mathrm{X} 3+$ $0.542 \mathrm{X} 4+(-0,145) \mathrm{X} 5$ dan kesimpulan hasil uji Kooefisien regresi dari :

a. Variabel X1, X2, X3 dan X4 bernilai positif, artinya variable ini ada hubungan positif dan searah terhadap variable terikat. Seandainya ada peningkatan nilai dari variabel bebas, maka variabel terikat nilainya juga akan naik. Variabel X5 tidak mempunyai hubungan positif atau searah terhadap variabel terikatnya.

b. Variabel tangibles (X1) memiliki nilai 0,177

c. Variabel reliability (X2) memiliki nilai 0,059

d. Variabel responsiveness (X3) memiliki nilai 0,364

e. Variabel assurance (X4) memiliki nilai 0,542

f. Variabel empathy (X5) memiliki nilai $-0,145$

Berdasarkan nilai seluruh variabel bebas yang digunakan, maka variabel yang memiliki pengaruh paling kuat adalah variabel tangibles, dan nilai koefisien regresi $=0,177$.

Tabel 6. ANOVA

\begin{tabular}{llrrrrr}
\hline Model & & Sum of & & & & \\
Squares & df & Mean Square & F & \multicolumn{1}{c}{ Sig. } \\
\hline 1 & Regression & 51.462 & 5 & 10.292 & 63.499 & $.000^{\mathrm{b}}$ \\
& Residual & 9.401 & 58 & .162 & & \\
& Total & 60.864 & 63 & & & \\
\hline
\end{tabular}

Tabel 7 Uji Regresi Linear Berganda

\begin{tabular}{|c|c|c|c|c|c|c|}
\hline \multirow[b]{2}{*}{ Mode } & & \multicolumn{2}{|c|}{ Unstandardized Coefficients } & $\begin{array}{l}\text { Standardized } \\
\text { Coefficients }\end{array}$ & \multirow[b]{2}{*}{$\mathrm{t}$} & \multirow[b]{2}{*}{ Sig. } \\
\hline & & $\mathrm{B}$ & Std. Error & Beta & & \\
\hline \multirow[t]{6}{*}{1} & (Constant) & .041 & .235 & & .175 & .862 \\
\hline & $\mathrm{X} 1$ & 177 & 148 & 179 & 1.197 & .236 \\
\hline & $\mathrm{X} 2$ & 059 & 132 & .052 & 442 & .660 \\
\hline & $\mathrm{X} 3$ & .364 & .117 & .354 & 3.111 & .003 \\
\hline & $\mathrm{X} 4$ & .542 & 208 & .505 & 2.610 & .011 \\
\hline & $\mathrm{X} 5$ & -.145 & .119 & -.147 & -1.217 & .228 \\
\hline
\end{tabular}

d. Uji korelasi

Untuk pengujian ini, digunakan Uji Korelasi Pearson, yang digunakan dalam mengukur kekuatan dan arah hubungan linier dari dua veriabel. Dua variabel akan disebut memiliki korelasi jika perubahan di sebuah satu variabel disertai dengan perubahan variabel lainnya, baik dengan arah yang sama ataupun dengan arah yang berbeda. 
Tabel 8 Uji Korelasi

\begin{tabular}{|c|c|c|c|c|c|c|c|}
\hline & & $\mathrm{X} 1$ & $\mathrm{X} 2$ & $\mathrm{X3}$ & $\mathrm{X} 4$ & $\mathrm{X} 5$ & $\mathrm{Y}$ \\
\hline \multirow[t]{5}{*}{$\bar{X} 1$} & Pearson Correlation & 1 & $.876^{* *}$ & $.868^{* *}$ & $.907^{* *}$ & $.756^{* *}$ & $.879^{* *}$ \\
\hline & Sig. (2-tailed) & & .000 & .000 & .000 & .000 & .000 \\
\hline & $\begin{array}{l}\text { Sumof Squares and } \\
\text { Crossproduct }\end{array}$ & 61.964 & 47.803 & 51.772 & 51.905 & 47.036 & 53.960 \\
\hline & Covariance & .984 & .759 & .822 & .824 & .747 & .857 \\
\hline & $\mathrm{N}$ & 64 & 64 & 64 & 64 & 64 & 64 \\
\hline \multirow[t]{5}{*}{$\mathrm{X} 2$} & Pearson Correlation & $.876^{* * 4}$ & 1 & $.845^{* * 4}$ & $.858^{* * 4}$ & $.729^{* * *}$ & $.834^{* * *}$ \\
\hline & Sig. (2-tailed) & .000 & & .000 & .000 & .000 & .000 \\
\hline & $\begin{array}{l}\text { Sumof Squares and } \\
\text { Crossproduct }\end{array}$ & 47.803 & 48.082 & 44.404 & 43.222 & 39.983 & 45.097 \\
\hline & Covariance & .759 & .763 & .705 & .686 & .635 & .716 \\
\hline & $\mathrm{N}$ & 64 & 64 & 64 & 64 & 64 & 64 \\
\hline \multirow[t]{5}{*}{$\bar{X} 3$} & Pearson Correlation & $.868^{* *}$ & $.845^{* *}$ & 1 & $848^{* *}$ & $.741^{* *}$ & $873^{* *}$ \\
\hline & Sig. (2-tailed) & .000 & .000 & & .000 & .000 & .000 \\
\hline & $\begin{array}{l}\text { Sumof Squares and } \\
\text { Crossproduct }\end{array}$ & 51.772 & 44.404 & 57.450 & 46.736 & 44.371 & 51.606 \\
\hline & Covariance & .822 & .705 & .912 & .742 & .704 & .819 \\
\hline & $\mathrm{N}$ & 64 & 64 & 64 & 64 & 64 & 64 \\
\hline \multirow[t]{5}{*}{$\overline{X 4}$} & Pearson Correlation & $907^{* *}$ & $.858^{* *}$ & $.848^{* *}$ & 1 & $.894^{* *}$ & $.881^{* *}$ \\
\hline & Sig. (2-tailed) & .000 & .000 & .000 & & .000 & .000 \\
\hline & $\begin{array}{l}\text { Sumof Squares and } \\
\text { Crossproduct }\end{array}$ & 51.905 & 43.222 & 46.736 & 52.819 & 51.354 & 49.941 \\
\hline & Covariance & .824 & .686 & .742 & .838 & .815 & .793 \\
\hline & $\mathrm{N}$ & 64 & 64 & 64 & 64 & 64 & 64 \\
\hline \multirow[t]{5}{*}{$\mathrm{X} 5$} & Pearson Correlation & $.756^{* *}$ & $.729^{* *}$ & $.741^{* *}$ & $894^{* *}$ & 1 & $.740^{* *}$ \\
\hline & Sig. (2-tailed) & .000 & .000 & .000 & .000 & & .000 \\
\hline & $\begin{array}{l}\text { Sumof Squares and } \\
\text { Crossproduct }\end{array}$ & 47.036 & 39.983 & 44.371 & 51.354 & 62.487 & 45.617 \\
\hline & Covariance & .747 & .635 & .704 & .815 & .992 & .724 \\
\hline & $\mathrm{N}$ & 64 & 64 & 64 & 64 & 64 & 64 \\
\hline \multirow[t]{5}{*}{$\bar{Y}$} & Pearson Correlation & $.879^{* *}$ & $.834^{* *}$ & $.873^{* *}$ & $.881^{* *}$ & $.740^{* *}$ & 1 \\
\hline & Sig. (2-tailed) & .000 & .000 & .000 & .000 & .000 & \\
\hline & $\begin{array}{l}\text { Sumof Squares and } \\
\text { Crossproduct }\end{array}$ & 53.960 & 45.097 & 51.606 & 49.941 & 45.617 & 60.864 \\
\hline & Covariance & .857 & .716 & .819 & .793 & .724 & .966 \\
\hline & $\mathrm{N}$ & 64 & 64 & 64 & 64 & 64 & 64 \\
\hline
\end{tabular}

Berdasarkan Tabel 8 Uji korelasi, dari nilai Signifikansi Sig (2-tailed) disimpulkan

a. Antara tangibles (X1) dengan Kualitas Layanan (Y) adalah sebesar 0,000 < 0,05, yang berarti terdapat korelasi yang signifikan antara variabel antara tangibles (X1) dengan Kualitas Layanan (Y), dari nilai $r$ hitung (Pearson Correlations) diketahui nilai $r$ hitung untuk tangibles (X1) adalah sebesar $0.879>\mathrm{r}$ tabel $0.244(64 \mathrm{~N})$, kesimpulannya ada hubungan atau korelasi untuk hubungan tangibles (X1) dengan Kualitas Layanan (Y).

b. Antara reliability (X2) dengan Kualitas Layanan (Y) adalah sebesar $0,000<0,05$, yang berarti terdapat korelasi yang signifikan antara variabel antara reliability (X2) dengan Kualitas Layanan (Y), dari nilai $r$ hitung (Pearson Correlations) diketahui nilai $r$ hitung 
untuk reliability $(\mathrm{X} 2)$ adalah sebesar $0.834>\mathrm{r}$ tabel $0.244(64 \mathrm{~N})$, kesimpulannya ada hubungan atau korelasi untuk hubungan reliability (X2) dengan Kualitas Layanan (Y).

c. Antara responsiveness (X3) dengan Kualitas Layanan (Y) adalah sebesar 0,000 < 0,05, yang berarti terdapat korelasi yang signifikan antara variabel responsiveness (X3) dengan Kualitas Layanan (Y), dari nilai r hitung (Pearson Correlations) diketahui nilai $r$ hitung untuk responsiveness (X3) adalah sebesar $0.873>\mathrm{r}$ tabel $0.244(64 \mathrm{~N})$, kesimpulannya ada hubungan atau korelasi untuk hubungan responsiveness (X3) dengan Kualitas Layanan (Y).

d. Antara assurance (X4) dengan Kualitas Layanan (Y) adalah sebesar 0,000 $<0,05$, yang berarti terdapat korelasi yang signifikan antara variabel antara assurance (X4) dengan Kualitas Layanan (Y), dari nilai $\mathrm{r}$ hitung (Pearson Correlations) diketahui nilai $\mathrm{r}$ hitung untuk assurance $(\mathrm{X} 4)$ adalah sebesar $0.881>\mathrm{r}$ tabel $0.244(64 \mathrm{~N})$, kesimpulannya ada hubungan atau korelasi untuk hubungan assurance (X4) dengan Kualitas Layanan (Y).

e. Antara empathy (X5) dengan Kualitas Layanan (Y) memiliki nilai 0,000 <0,05, artinya ada korelasi signifikan diantara variabel empathy (X5) serta Kualitas Layanan (Y), dari nilai $\mathrm{r}$ hitung (Pearson Corelations), didapatkan nilai $\mathrm{r}$ hitung untuk empathy (X5) adalah sebesar $0.740>\mathrm{r}$ tabel $0.244(64 \mathrm{~N})$, kesimpulannya ada hubungan atau korelasi diantara empathy (X5) dengan Kualitas Layanan (Y).

Setelah empat komponennya diketahui, akan dimasukkan ke dalam rumus berikut.

$$
\begin{aligned}
& \frac{b_{\mathrm{x}^{\mathrm{I}}} \text {. } \text { crossproduct } \mathrm{R}^{2}}{\text { Regression }} \\
& \mathrm{b}=\text { koefisien } \mathrm{b} \text { dari komponen } \mathrm{x} \\
& \mathrm{CP}=\text { cross product dari komponen } \mathrm{x} \\
& \text { Regressions }=\text { nilai regresi } \\
& \mathrm{R}^{2}=\text { sumbangan effektif total }
\end{aligned}
$$

Tabel 9. Sumbangan Efektik

\begin{tabular}{lrlllr}
\hline Variabel X & b & Coss Product & Regresi & $\begin{array}{l}\text { Sumbangan } \\
\text { Efektif Total }\end{array}$ & $\begin{array}{l}\text { Sumbangan Efktif } \\
\text { Komponen }\end{array}$ \\
\hline X1 & 0.177 & 61.964 & 51.462 & $84 \%$ & 17.90 \\
X2 & 0.059 & 47.803 & & & 4.60 \\
X3 & 0.364 & 51.772 & & & 30.76 \\
X4 & 0.542 & 51.905 & & & 45.92 \\
X5 & -0.145 & 47.036 & & & -11.13 \\
\hline
\end{tabular}

\section{e. Service Quality}

Dari hasil kuisioner dapat diketahui nilai dari fakta, harapam serta gap sesuai dengan dimensi Kualitas Layanan, terlihat pada Tabel 9

Table 10. Fakta, Harapan dan Gap berdasarkan nilai Kualitas Layanan (Service Quality)

\begin{tabular}{lcccc}
\hline Variabel & $\begin{array}{l}\text { Total } \\
\text { Harapan }\end{array}$ & $\begin{array}{l}\text { Total } \\
\text { Fakta }\end{array}$ & $\begin{array}{l}\text { Gap }= \\
(\mathrm{P}-\mathrm{H})\end{array}$ & $\begin{array}{l}\mathrm{Q}= \\
(\mathrm{P} / \mathrm{H})\end{array}$ \\
\hline $\mathrm{X} 1$ & 4.31 & 3.51 & -0.8 & 0.81 \\
$\mathrm{X} 2$ & 4.35 & 3.80 & -0.55 & 0.87 \\
$\mathrm{X} 3$ & 4.38 & 3.69 & -0.69 & 0.84 \\
$\mathrm{X} 4$ & 4.29 & 3.54 & -0.75 & 0.83 \\
$\mathrm{X} 5$ & 4.26 & 3.67 & -0.59 & 0.86 \\
$\mathrm{Y}$ & 4.32 & 3.62 & -0.7 & 0.84 \\
\hline
\end{tabular}


Seandainya Nilai dari Kualitas $(\mathrm{Q})=1$, maka dikatakan kualitas layanan baik. Sesuai dengan nilai pada tabel, Kualitas $(\mathrm{Q})<1$ yang memilikik sejumlah 5 dimensi yaitu assurance, tangible, reliability, responsiveness dan empathy dan kesimpulannya kualitas layanan masih belum baik.

\subsection{Diskusi}

Dari penelitian ini ditemukan gap yang menyatakan bahwa kualitas layanan belum baik, hasil ini sama dengan beberapa penelitian-penelitian sebelumnya yang menjadi referensi. Namun nilai rata-rata gap $=0.68$ pada penelitian ini bila dibandingkan dengan penelitian $\mathrm{W}$. Utama[14] yang rata-rata gap $=1.166$, maka nilai gap pada penelitian ini lebih kecil, demikian juga bila dibandingkan dengan penelitian $M$. Jebraeily[11] yang nilai gap=1.2. Namun jika dibandingkan dengan penelitian N. Luh[18] didapatkan gap=0.02, maka gap dari penelitian ini lebih besar. Dari penelitian yang sama-sama menggunakan metode servqual, didapatkan hasil yang berbeda. Hal ini salah satunya disebabkan dengan kriteria dari responden. Dimana pada penelitian ini, reseponden adalah mahasiswa Fasilkom yang sudah terbiasa menggunakan aplikasi, dan pada penelitian N. Luh[18], respondennya adalah dosen komputer yang memang secara umum sudah sangat menguasai pembuatan dan penggunaan aplikasi. Jadi dari analisa referensi dan hasil penelitian yang dilakukan, maka didapatkan sebuah kesimpulan terkait penggunaan metode ini dalam mengukur mengukur kualitas layanan sistem informasi, dimana kriteria responden perlu dimasukkan menjadi variabel penelitian. Karena responden yang berlatar belakang ilmu komputer akan memiliki nilai kesulitan yang lebih kecil bila dibandingkan responden tanpa latar belakang ilmu komputer, terkait dengan pemanfaatan aplikasi dan sistem informasi.

\section{Kesimpulan}

Koefisien regresi variabel X1, X2, X3 dan X4 menunjukkan angka yang positif, artinya variabel ini memiliki hubungan positif atau searah terhadap variabel terikatnya. Jika nilai variabel bebas bertambah nilainya, maka variabel terikat akan ikut bertambah. Dan untuk variabel X5 tidak mempunyai hubungan positif atau searah terhadap variabel terikatnya.

Hasil uji korelasi memakai aplikassi SPSS, memperlihatkan hubungan positif serta signifikan dari 5 (lima) variable bebas, yaitu variabel assurance, tangible, reliability, responsiveness, serta empathy dari Kualitas Layanan Sistem Informasi SMART Unilak.

Kontribusi variabel tangibles; reliabilitys; responsivenes; assurance, serta empathy untuk menambah Kualitas Layanan pada PDPT Unilak secara berurutan adalah sebesar $17.90 \%$, $4.60 \%, 30.76 \%, 45.92 \%,-11.13 \%$

Berdasarkan perhitungan nilai dari Service Quality didapatkan kesenjangan atau Gap dari setiap variable bebas yakni tangibles; reliabilitys; responsivenes; assurance, serta empathy adalah $-0.8,-0.55,-0.69,-0.75,-0.59$. Hasi dari pengukuran menyimpulkan bahwa kualitas yang berdasarkan nilai tangible, reliability, responsiveness, assurance, dan empathy masih kurang baik. Jadi tingkat kepuasan pengguna akan Kualitas Layanan Sistem Informasi PDPT Unilak masih kurang puas.

Kontribusi penelitian ini berguna bagi PDPT Unilak dalam menentukan kebijakan yang tepat untuk peningkatan kualitas layanan, karena penelitian ini memberikan hasil kepuasan mahasiswa Fasilkom terkait layanan SMART Unilak dan PDPT Unilak.

Penelitian ini juga memberikan implikasi bagi penelitian sejenis berikutnya, khususnya dalam menentukan responden, karena dari penelitian ini, diketahui bahwa latar belakang responden memberikan pengaruh terhadap hasil kuisioner.

\section{Daftar Pustaka}

[1] V. M. Ngo and H. H. Nguyen, "The relationship between service quality, customer satisfaction and customer loyalty: An investigation in Vietnamese retail banking sector," J. Compet., 2016.

[2] E. Garga and A. J. Bambale, "The Impact of Service Quality on Customer Patronage: 
Mediating Effects of Switching Cost and Customer Satisfaction.," Int. J. Glob. Bus., vol. 9, no. 1, 2016.

[3] P. Nambisan, D. H. Gustafson, R. Hawkins, and S. Pingree, "Social support and responsiveness in online patient communities: impact on service quality perceptions," Heal. Expect., vol. 19, no. 1, pp. 87-97, 2016.

[4] P. Kotler and G. Armstrong, Principles of marketing. Pearson education, 2010.

[5] H. Fadil, K. Singh, and C. Joseph, "The influence of organizational innovation towards internal service quality in MBKS," Procedia--Social Behav. Sci., vol. 224, pp. 317-324, 2016.

[6] P. Sharma, T. T. C. Kong, and R. P. J. Kingshott, "Internal service quality as a driver of employee satisfaction, commitment and performance," J. Serv. Manag., 2016.

[7] V. A. Zeithaml and A. Parasuraman, Service Quality. Marketing Science Institute, 2004.

[8] M. Kumar, K. S. Sujit, and V. Charles, "Deriving managerial implications through SERVQUAL gap elasticity in UAE banking," Int. J. Qual. Reliab. Manag., 2018.

[9] M. Mujinga, "Retail banking service quality measurement: SERVQUAL gap analysis," in 2019 Conference on Information Communications Technology and Society (ICTAS), 2019, pp. 1-6.

[10] M. Khadem Rezaiyan and others, "Quality Gap in educational services based on SERVQUAL Model in Mashhad Medical School,” Res. Med., vol. 40, no. 1, pp. 17-23, 2016.

[11] M. Jebraeily, B. Rahimi, Z. Zare Fazlollahi, and H. Lotfnezhad Afshar, "Using SERVQUAL model to assess hospital information system service quality," Hormozgan Med. J., vol. 23, no. 1, p. e86977, 2019.

[12] Y. Wismantoro, H. Himawan, and K. Widiyatmoko, "The effect of IS SERVQUAL and user information satisfaction (UIS) adoption on user satisfaction," Uncertain Supply Chain Manag., vol. 8, no. 3, pp. 495-504, 2020.

[13] W. Wahyudi, R. Ruliah, and Y. Yudihartanti, "Analisa Tingkat Kualitas Pelayanan Diklat Prajabatan BKD Banjarbaru Menggunakan Metode Servqual," Jutisi J. Ilm. Tek. Inform. dan Sist. Inf., vol. 5, no. 3, 2017.

[14] W. Utama, W. Lestari, and D. R. Ikmaluhakim, "Pengukuran Kepuasan Pasien Terhadap Pelayanan Puskesmas Dengan Metode Servqual (Studi Kasus: Puskesmas Ngagel Rejo Surabaya)," 2017.

[15] M. S. Paramita, W. A. P. Dania, and D. M. Ikasari, "Penilaian Kepuasan Konsumen Terhadap Kualitas Pelayanan Menggunakan Metode Servqual (Service Quality) Dan Six Sigma (Studi Kasus Pada 'Restoran Dahlia' Pasuruan)," Ind. J. Teknol. dan Manaj. Agroindustri, vol. 4, no. 3, pp. 102-115, 2017.

[16] A. P. Rahayu, H. B. Santoso, and S. Rahayuningsih, "Analisa Kepuasan Sistem Informasi Akademik Mahasiswa Menggunakan E-Servqual," JATI UNIK J. Ilm. Tek. dan Manaj. Ind., vol. 2, no. 1, pp. 55-63, 2019.

[17] R. Ekasari, M. S. Pradana, G. Adriansyah, M. A. Prasnowo, A. F. Rodli, and K. Hidayat, "Analisis Kualitas Pelayanan Puskesmas Dengan Metode Servqual," J. Darussalam J. Pendidikan, Komun. Dan Pemikir. Huk. Islam, vol. 9, no. 1, pp. 86-93, 2017.

[18] N. Luh, A. Kartika, and Y. Sarja, "Pengukuran Kepuasan Pengguna Sistem Informasi Dosen Menggunakan Metode Servqual,” J. Sist. DAN Inform., pp. 19-25, 2018.

\section{(i) (2)}

ar sh Digital Zone: Jurnal Teknologi Informasi dan Komunikasi is licensed under a_Creative Commons Attribution International (CC BY-SA 4.0) 